\title{
Magical Realism and Allegory in Joseph SKIBELL'S A BLESSING ON THE MOON
}

\begin{abstract}
This paper analyzes Skibell's novel A Blessing on the Moon (1997), focusing on elements of the book's magical realism and allegory. It sets out to interpret Skibell's transposition of the Holocaust to his own experience as a representative of the post-Holocaust generation. Finally, the paper explores the ethical problems of this approach to the Holocaust - an approach that relies heavily on imagination. The interpretation of Skibell's novel demonstrates that the imaginative enactment of the tragic traumatic events cannot be dismissed as a mere appropriation of the Holocaust or as a form of "identity theft"; instead it must be seen as the author's genuine attempt to come to terms with the original trauma of his ancestors. In Skibell's case it is his great-grandfather Chaim Skibelski whose voice was silenced in the war and who becomes the protagonist of the novel.
\end{abstract}

Keywords

Holocaust; Joseph Skibell; magical realism; allegory, the fantastic; postmemory; trauma

The Jewish American writer Joseph Skibell (born 1959), the grandson of a Jewish immigrant from Poland, represents the third generation of post-Holocaust authors whose response to the Nazi genocide is inevitably determined by their lack of direct experience of the terror of World War II. Their connection to the tragic past of their predecessors is shaped by postmemory - the result of a transgenerational transference of traumatic memory - and is mediated by narratives based on a rich imagination. Skibell's controversial novel A Blessing on the Moon (1997) was inspired by the fate of his great-grandfather Chaim Skibelski, who perished in the Holocaust. In fact, the name of the novel's protagonist is identical with 
that of his great-grandfather. Some critics praised Skibell's imaginativeness and originality, whereas others criticized him for allegedly trivializing the Holocaust and relativizing the consequences of the genocide. For example, in Marita Grimwood's view, Skibell's novel "forms a particularly original addition to the Holocaust 'canon"" (2007: 83), and Patrick Giles sees it as "a confirmation that no subject lies beyond the grasp of a gifted, committed imagination" (1997: 12). On the other hand, Alvin Rosenfeld has claimed that Skibell tended "to reduce the victims of the Jewish disaster under Hitler to the kinds of figures one finds in fairy tales" and that "[w]hoever the real Chaim Skibelski was, the character who bears his name in 'Blessing on the Moon' fails to bring about his imaginative restoration" (1997: 15). Essentially, those critics who responded negatively to the novel were disturbed above all by the inauthenticity of Skibell's story.

The contradictory reception of Skibell's novel demonstrates one serious problem of Holocaust literature - the issue of the representation and representability of the Holocaust in fiction. This is connected with the problem of the adequacy or inadequacy of responses to the tragic events of World War II. With respect to the direct experience of wartime events, it is understandable why authenticity became one of the central tenets in the writings of the first generation of Holocaust writers, who were survivors of the genocide. Their works are rooted in documentary realism. This literary mode has given rise to numerous Holocaust autobiographies and testimonies. Elie Wiesel's books, such as Night (1958 in French, 1960 in English) or All Rivers Run to the Sea: Memoirs (1995), can serve as an illustrative examples of this approach to Nazi atrocities. However, given the fact that memory is distorted by trauma, even these writers ran the risk of offering a biased representation of the Holocaust. Trauma theorists point to the essential inaccessibility of the traumatic events at the very moment of their occurrence, to the failure to grasp fully their meaning. Therefore even the direct survivors of the Holocaust face the problem of the representation of this historical event. According to Shoshana Felman, "testimony seems to be composed of bits and pieces of a memory that has been overwhelmed by occurrences that have not settled into understanding or remembrance, acts that cannot be construed as knowledge nor assimilated into full cognition, events in excess of our frames of reference" (1995: 16). Moreover, the danger of the distortion of reality is complicated by the problem of the unspeakability of the terror of the Holocaust and the inadequacy of language for addressing the inconceivable brutality experienced in the death camps. Nevertheless, these writers' attempt to depict their experience was driven by the conviction that even an imperfect articulation is a better response to such an atrocity than silence.

The second and third generation of writers (generally I use the term "postHolocaust generation") have compensated for a lack of immediate experience by their use of imagination. Marianne Hirsch, who calls the post-Holocaust generation the "generation of postmemory," speaks of "imaginative investment" (2008: 107). It is imagination that forms these writers' postmemory - a phenomenon which "describes the relationship that the generation after those who witnessed 
cultural or collective trauma bears to the experiences of those who came before, experiences that they 'remember' only by means of the stories, images, and behaviors among which they grew up" (Hirsch, 2008: 106). Post-Holocaust authors' imaginative - or antirealistic - approach to the cataclysmic events of the Holocaust is characterized by the use of highly figurative (metaphorical) language and the employment of the fantastic, allegory, fable, Jewish folklore, and last but not least, magical realism. As Jenni Adams suggests, magical realism "offers an important strategy in attempts to continue the project of Holocaust representation into the post-testimonial era, permitting a form of literary engagement with these events that nevertheless acknowledges its ethical and experiential distance from the real" (2011: 1-2). Since it questions conventional modes of narrative (for example testimony, autobiography, diary or what is sometimes generally termed documentary fiction) and deviates from a merely mimetic approach to reality, such artistic treatment of the Holocaust was not always welcomed by the authors-survivors, for whom faithfulness to history was sacred. It is true that post-Holocaust writers, having only vicarious experience, face many pitfalls and limitations. They are exposed to the danger of simplification or trivialization of the Holocaust, its aestheticization, and the replacement of history by mythmaking. According to Ruth Franklin, their antirealistic approach leads to a distortion of reality - or, as she put it, "identity theft" (2011: 215-234). Particularly in the context of the fiction written by the post-Holocaust generation, she expresses her concern about the potential abuse of their writing, noting that "[c]ritics of Holocaust literature have often worried that the fictional representation of the camps can give fodder to Holocaust deniers" (2011: 233). The question of what constitutes an adequate response to the Nazi genocide poses not only an aesthetic problem, but also an ethical one. Writers of the second and third generation (such as Joseph Skibell, Jonathan Safran Foer, Art Spiegelman, Thane Rosenbaum, Melvin Jules Bukiet and many others) have to deal with the question of how to avoid being accused of the appropriation and/or exploitation of the Holocaust.

However difficult the post-Holocaust writers' dilemma of whether they should remain silent about the Holocaust or whether they should attempt to express the inexpressible and to imagine the unimaginable, for them the resolution of this dilemma is evident. Since the Holocaust is a vital part of their identity due to their family history, they feel an urge to address it through writing. As Victoria Aarons asserts,

[f]or the children of survivors, the Holocaust becomes the psychic and emotional site of the originating, defining - if delayed - moment of trauma. To be sure, for the second-generation writers, the Holocaust has ineradicably shaped their lives, but as a kind of silhouette, for the 'memories' of such defining events are 'borrowed,' 'secondhand,' so that not even the memories are the writers' own (2012: 139-140).

An important argument is that the main subject of these writers' books is not the Holocaust per se, but rather their own experiences, shaped by the traumatic 
legacy of their parents or grandparents, as well as the effects of the Holocaust on the (grand)children of survivors - though this does not apply to Skibell's novel.

Gaps in offspring's knowledge of their grand/parents' history, and the impossibility of fully grasping their trauma, fuel the imagination of the post-Holocaust generation. Their need to fill the void may even lead to an obsession with the Holocaust, as some stories by such authors as Thane Rosenbaum and Melvin J. Bukiet suggest. In fact, imagination - together with knowledge acquired from non-fiction books on the Holocaust and survivors' testimonies - is the only source they can rely on; it substitutes for a lack of personal experience. As Bukiet argues, "[f]or anyone who wasn't there, on either side of the barbed wire, Jew or German, thinking about the Holocaust is really an act of imagination. All we know is how little we know" (2002: 16). Imagination as the key strategy of the post-Holocaust writers raises the question whether the use of elements of the fantastic, magical realism and allegory - all substantial elements of Skibell's novel - is genuinely an inappropriate representation of the Holocaust. Stephen Gunther gives an apt response to all doubting voices: "In a universe in which the historically real seems so fantastic as to exceed any parameters for comparison and contextualization, recourse to the fantastic may be an adequate rhetorical strategy to examine the moral significance of the Holocaust" (2000: 193). Imaginative investment in Holocaust literature is justifiable because the Holocaust reality itself is inconceivable, beyond our scope of understanding. By casting aside the demand for authenticity, the post-Holocaust authors violate all the accustomed conventions of Holocaust narratives from the earlier period. In their innovative approaches to the victims' experience, they test new ways and possibilities of addressing their inherited trauma, responding to the call for new forms of expression. They search for new narrative modes or strategies, radically different from eyewitness testimonies and more traditional forms of Holocaust fiction. In their countercultural, alternative narratives, subverting the topic, they utilize postmodern techniques which are in accordance with their view of the historical events they address. As Efraim Sicher suggests, "[t]he Holocaust is often spoken of as a paradigmatic catastrophe, a seismic event that exceeds all boundaries of the imagination and that defies measurement or understanding. It has become the supreme postmodern event" (2005: 175). To be sure, even if the writers of the second and third generation employ imagination to an excessive degree (though it is only in terms of the extent of its use that they differ from traditional authors, because all fiction draws on imagination), this does not mean that they ignore the historical reality of the Holocaust. Their works are deeply informed about the most appalling sufferings of the victims, including their experience of ghetto life, transportation in cattle cars, and of course the death camps.

In A Blessing on the Moon Skibell not only utilizes magical realism; he also draws on the tradition of Jewish folk narratives, fairy tales and Hasidic tales as a way of creating a connection with the spiritual world. As far as magical realism is concerned, there are so many definitions of this approach to writing, sometimes contradictory, that this essay does not seek to arrive at one single satisfactory 
characterization. As a matter of fact, the Mexican writer Jorge Volpi does not hide a certain aversion to the proliferation and debasement of this term, claiming that due to South American and Western media, the term "magical realism" has become a dangerous stereotype and a vehicle of aesthetic dictate (2014: 18). Nevertheless, we may agree that magical realist texts are based on the defamiliarized presentation of events, whereby the familiar becomes unusual. In these texts, "[w]e are transported from the domain of the real to the magically real by the similarly uncharted strategems of the artistic imagination" (Danow 1995: 68) and "two contrasting views of the world (one 'rational' and one 'magical') are presented as if they were not contradictory" (Spindler 1993: 78). It enables the coexistence of the natural and the supernatural, the real and the unreal within the text. What matters is readers' perception of the supernatural as part of everyday reality, their acceptance of the fictional illusion of a phenomenon as if it were a part of reality and real-life experience, due to the matter-of-fact presentation of magical or supernatural events. Attention to details and the narrative strategy of verisimilitude take these texts close to realism. Texts written in a magical realistic mode integrate real and fantastic elements so that the reader does not perceive them as mutually exclusive or disruptive. To summarize this in Faris's words, "magical realism combines realism and the fantastic in such a way that magical elements grow organically out of the reality portrayed" (2005: 163). In the case of Skibell's novel (similarly to postcolonial literature), magical realism is an expression of the traumatic imagination in which "fantastic re-presentation (imaginative reconstitution) works where realistic representation (descriptive mimesis) has apparently failed" (Arva 2008: 61). Here the historical trauma is presented from a post-Holocaust perspective, for the reasons which have been outlined above.

A Blessing on the Moon is written in a type of richly metaphorical language that is one of the inherent features of magical realism. Its story is told from the perspective of the protagonist Chaim Skibelski, the autodiegetic narrator. Already the initial scene is conceived in a magical realistic way. Similarly to Saul Bellow's Mr. Sammler's Planet (1970), the protagonist emerges from a mass grave where a German killing squad murdered his fellow Jews. The mode of the scene is realistic, based on real events that occurred when the Einsatsatzgruppen death squads carried out mass killings of Jews. What makes the whole scene magical is that while Bellow's Sammler crawls out of the grave alive, Chaim climbs out of the grave dead. The difference between the realistic and antirealistic depiction of the similar event is visible when comparing both scenes:

Yes, go and find it when everyone is murdering everyone. When Antonina [Sammler's wife] was murdered. When he himself underwent murder beside her. When he and sixty or seventy others, all stripped naked and having dug their own grave, were fired upon and fell in. Bodies upon his own body. Crushing. His dead wife nearby somewhere. Struggling out much later from the weight of corpses, crawling out of the loose soil. Scraping on his belly. Hiding in a shed. Finding a rag to wear. Lying in the woods many days (Bellow 1973: 92). 
It all happened so quickly. They rounded us up, took us to the forests. We stood there, shivering, like trees in uneven rows, and one by one we fell. No one was brave enough to turn and look. Guns kept cracking in the air. Something pushed into my head. It was hard, like a rock. I fell. But I was secretly giddy. I thought they had missed me. When they put me in the ground, I didn't understand. I was still strong and healthy. But it was useless to protest. No one seemed to hear the sounds I made or see my thrashings, and anyway, I didn't want to draw attention to myself, because then they would have shot me.

I was lying in a pit with all my neighbors, true, but I was ecstatic. I felt lighter than ever before in my life. It was all I could do not to giggle.

And later, as dusk gathered, I climbed out of the grave, it was so shallow, and I ran through the forests. Nobody saw me. I ran with the dirt in my mouth. I had to spit it out as I ran.

$$
\text { [...] }
$$

And I realized I was dead. But why was I not in the World to Come? (Skibell 1998: 3-5)

Bellow's depiction of his protagonist's most traumatic experience and his miraculous survival is very laconic; it takes place only in his brief flashback. Miracles happen: the reader therefore has no trouble believing that Sammler was only wounded and then buried under just a thin layer of soil, so he was able to free himself from the grave. Skibell's portrayal of the mass killing of Jews by shooting is also very realistic; however, what makes his text different, and what may trouble the reader, is the sentence "And I realized I was dead." The whole novel is a ghost story about the protagonist's afterlife and his search for the elusive World to Come. If a reader has problems trusting the story from the moment of the realization of Chaim's death, yet still eventually accepts this fantastic phenomenon as reality, it is because the narrator acts as if he were a living person. In his own unique way, Skibell contributes to the rich tradition of ghosts in U.S. and Latin American fiction written in the magical realist mode (Toni Morrison's novel Beloved may serve as one of the canonical examples).

Another magical moment in Skibell's novel is Chaim's invisibility after his death. As a restless, ghostly, invisible man, he witnesses the destruction of the Jewish world in his village: "When I got to our village, everything was gone. A dozen workmen were lifting all the memories into carts and driving off" (4, emphasis mine). By using the word "memories" instead of writing of material things, Skibell not only poeticizes his text but also places emphasis on the disruption of spiritual heritage as well as the loss of material possession. Chaim helplessly observes his house, now occupied by his anti-Semitic Polish neighbors who have blatantly appropriated all his family's property. The spectral main character is destined only to observe the joy of his neighbors, rejoicing at the easy acquisition of his family's valuable things without being troubled at what expense they obtained them. It has symbolic significance that the only person from the family of 
intruders who can see Chaim is the youngest daughter Ola, a highly sensitive girl who is ashamed by the boorish behavior of her family members and feels guilty for the liquidation of the Jews. Chaim and the empathetic Ola establish a close and conspiratory relationship, imbued with a sense of understanding which overlaps into eroticism. Since Ola is the "other," she does not fit into the vulgar world of intruders and violence and thus she must die. Her incurable illness symbolizes her feelings of guilt for the Polish bystanders' treatment of Jews and their complicity in the genocide. Yet Skibell's incorporation of this character into his story implies that not all the bystanders acted in the same culpable way. Her death echoes the destiny of the Jews during the Holocaust. The Christian symbolism of her ascending to the heavens in a fiery chariot, guided by four horses with lion's heads and carrying Jesus and Mary, implies an encounter (yet at the same time also a clash) of two different cultures. Although Chaim perceives the death of his companion as a very painful loss, he is disturbed by the Christian content of her departure: "Oh, but the misery of watching her ascend to the Heavens..., accompanied by her false gods, those idolatrous abominations, while our God, the One True God, has left me neglected here below, answering my pleas with His stony, implacable silence!" (59). Being discontented with the events around him, he rails against his God, seeing God's indifference as injustice.

Children in Holocaust literature often represent a contrasting world to the cruelties and atrocities perpetrated by adults, and in this respect Ola is no exception. Her empathy with the suffering of the persecuted Jews contrasts with the blindness and insensitivity of the adult members of her family, who serve as a synecdoche for a considerable segment of Polish society in World War II. Naomi B. Sokoloff sees Jewish children in Holocaust fiction as "the Other of the Other" (1992: 8), and although Ola is not a part of a minority culture, her fatal illness and moral stance - as well as her affinity with Chaim - places this bystander alongside the victims, and justifies our view of her as a figure marked by "double otherness."

Despite the presence of the character of Ola, Skibell's picture of the Polish bystanders is largely negative. Chaim observes with disgust the falsity of the ceremonial feast of mourning which takes place in his house after Ola's death. The demise of the girl who was "too good for this harsh world" (59) is depicted as merely an opportunity for the mourners to throw a party which lacks any spiritual dimension. It turns into an occasion for excessive eating and drinking, and even for anti-Semitic diatribe. When the narrator (as a ghost) attempts to expel the mourners from his house by scaring them, the already drunk Andrzej, the head of Ola's family, shouts at him "you christkilling yid" (63). A time supposedly devoted to piety is dominated by vulgarity and earthbound materialism. Negative features of bystanders are also embodied by Chaim's former office colleagues, who show callous indifference to the massacre of the Jews from the village. From his position of invisibility he observes their ignorance of the suffering of his entire nation: "I pass among them unnoticed, unfelt, possibly unremembered, not unlike all their colleagues who disappeared that day into the pit. To them, it is no 
different than if I had sold the business and taken half the workers with me. We are gone. Simply. No one cares where" (16-17).

There are many other elements of magical realism in Skibell's novel. One of them is the Kafkaesque metamorphosis of a rabbi, accompanying the narrator in his wandering to the World to Come, into a crow - a talking bird, reminiscent of Bernard Malamud's “The Jewbird." At the novel's end, he is transformed into a young woman. The rabbi functions as the protagonist's moral and spiritual guide, and simultaneously as the source of faith for all the slaughtered Jews. Therefore when he revisits the site of his death, and hears the voices of slain Jews coming out of the grave, being asked by them about the rabbi, he hesitates to reveal the truth about the rabbi's actual form, in order not to deprive them of hope they pinned on him. Knowing that the rabbi, as a moral authority, represents salvation for them, he cannot find the strength to admit that the rabbi abandoned him. Lonely and wandering with a stick in his afterlife (as if he were a figure of a vanishing beggar taken from Chagall's painting), he chooses a merciful lie, holding back the real truth: "How can I tell them that the Rebbe became a crow and flew away?" (26). The voices in Yiddish, emanating from the grave, can be interpreted as the vox populi of the whole nation.

In another surreal scene, Chaim Skibelski and the rabbi visit the mass grave again in winter. In the peaceful atmosphere of the place, blanketed with snow and forming a contrast with the violence committed against the Jewish victims there, the flying rabbi utters magical phrases in Hebrew and Aramaic and the grave opens. The rabbi and Chaim see the decomposed and mutilated bodies of buried villagers. This magical realistic scene evokes decay and destruction, paralleled with the destruction of the Jewry in the Holocaust. Yet at the same time it opens the door for hope, symbolizing the indestructibility of Chaim's nation and its continuity, because the buried Jews live their afterlife:

With a dirty hand, Basha Rosenthal wipes a tear from a lost eye. Her child plays at her broken feet, without its jaw.

Rivke Siedenberg, my old seductress, bravely holds her disemboweled viscera in with two unsteady arms.

A man I can no longer identify uses two pincer-like fingers to delicately extract a worm from the cavity in his blackened cheek. He pulls and pulls at its slithering tail, curling it in loops around his little finger (77).

These moving images attest to Arva's assertion that "[t]he deceptive simplicity of magical realist images, their coherence, vividness, and emotional charge, enables readers to see and to feel - without necessarily understanding - the indescribable horrors of the past" (Arva 2008: 75).

The rabbi transformed into a crow is not the only animal presented in a magical realistic fashion. The narrator, accompanied by the procession of murdered Jews in their search for the World to Come, meets a pack of wolves, one of which has the ability to talk. The wolf engages in a dialogue with Chaim, accusing him of 
trespassing on their territory. In fact animal imagery appears very frequently in Holocaust literature, and it may perform various functions. For example, in Art Spiegelman's Maus ( $1^{\text {st }}$ volume 1986, $2^{\text {nd }}$ volume 1991), the images of animals basically serve as allegories - though in certain situations they are used with symbolic meanings. Spiegelman's animals stand for individual nations - mice for Jews, cats for Nazi Germans, pigs for Poles, dogs for Americans, frogs for the French, bees for the Gypsies etc. More common is the use of images of animals with symbolic and metaphorical functions. In Jerzy Kosinski's novel The Painted Bird (1965) - whose title, similarly to Maus, calls the reader's attention to animals - the central image of the painted bird appropriately expresses the tension between individualism and collectivism, between both the need to belong and the need to stay independent, yet it also enabled Kosinski to find a very exact metaphor for the otherness of the novel's narrator, a nameless uprooted Boy, who due to his difference becomes a victim of violence, a hopeless outsider, rejected by the community. Cynthia Ozick too, in her book The Shawl (together with the novella Rosa in 1989), incorporated various animals into her story about the victims of the Holocaust - from squirrel to tiger, wolf to butterfly, functioning as metaphors. Generally, the animal imagery in Holocaust literature conveys the overall dehumanization of mankind during the deranged times of World War II. It indicates the victims' loss of their human status as a result of their exposure to the brutal animalistic behavior of the perpetrators, but it also signifies the relationship between perpetrators, bystanders, and victims during the Nazi genocide and clearly exemplifies the predatory nature of Nazism. In this respect, Skibell's A Blessing on the Moon is no exception, although his novel does not employ images of animals so intensely and systematically.

Hand in hand with the magical approach to reality, Skibell also uses various modes of writing that are characteristic of realism to give the impression of reality and create a sense of verisimilitude, thus disguising the improbability of certain situations. The best example from his book may be the scene in which Chaim Skibelski becomes aware of the reality of his posthumous existence when he catches a glimpse of his maimed face and deformed body on the surface of the pond which mirrors his physical appearance:

...I see, for the first time since I was shot, a reflection of my face. One side is entirely missing, except for an eye, which has turned completely white. Barely hanging in its socket, it stares at itself in an astonished wonder. My grey beard is matted thick with blood, and broken bits of bone protrude here and there through the raw patches of my flesh.

I look like a mangled dog carcass. (11)

Paying attention to details in this realistic, or rather naturalistic, description of the grotesque body, he creates the same effect of the semblance of truth as that which featured prominently in the classic realist literature of the $19^{\text {th }}$ century. The verisimilitude draws on its believability, as the reader can imagine the 
repulsive physical state of the human body after its massacre and burial in the grave.

On the other hand, in other sections of the novel, Skibell crosses the boundaries of believability and enters the realm of the fantastic - when we, as readers, are hesitant to accept the literal reality of the strange events. We admit that drawing a line between the reader's/character's acceptance and rejection (or at least his/her confusion) is highly problematic. Tzvetan Todorov explains the fantastic as a hesitation between two ways of explaining an uncanny phenomenon - "by types of natural causes and supernatural causes" (1975: 26). He argues:

The fantastic requires the fulfillment of three conditions. First, the text must oblige the reader to consider the world of the characters as a world of living persons and to hesitate between a natural or supernatural explanation of the events described. Second, this hesitation may also be experienced by a character; thus the reader's role is so to speak entrusted to a character, and at the same time the hesitation is represented, it becomes one of the themes of the work - in the case of naïve reading, the actual reader identifies himself with the character. Third, the reader must adopt a certain attitude with regard to the text: he will reject allegorical as well as "poetic" interpretations. (1975: 33)

There is the scene in which the narrator comes across the disembodied head of a German soldier who may have shot him and who has now himself become a victim of the ceaseless chain of killing. With the roles reversed, the head - now totally dependent on Chaim's help - begs for forgiveness. However, for the protagonist it is difficult to resolve the moral dilemma of whether or not to forgive him, because human compassion is mixed with hatred in him. Although the talking head regrets its deeds, Chaim has many reasons for vengeful feelings: "'Little head,' I say, 'when you killed me, you took everything. My home, my wife, my children. Must you have my forgiveness as well?"' (112). At the same time, the head of the "sentimental murderer" (104) is humanized by the narrator when the reader learns that it originally belonged to a student of music composition. Yet, in spite of the head's remorse, it does not refrain from expressing its deep-rooted anti-Semitism, when accusing Chaim of the ruination of its life: “'If it weren't for you,' it says, 'I'd still be at the conservatory, working on my compositions"' (98). The fantastic episode featuring the head of the German soldier "allows Skibelski to confront the injustice of his death" (Stadden 2005: 156). Chaim's encounter with the talking severed head is presented in a matter-of-fact way without any sign of the protagonist's astonishment. In this respect, the rendition of the entire event seems to be close to the magical realist mode. We can notice that Todorov's second condition for the definition of the fantastic is not fulfilled here. However, as Todorov explicitly states, when constituting the fantastic, the second condition "may not be fulfilled" (1975: 33, emphasis mine). The truth is that in the context of Skibell's novel, readers (if they are not naïve) may hesitate in their approach 
to this episode, and thus they may be disturbed by their lack of resolution. In this postmodern fashion, Skibell manages to destabilize the reader.

One of the key magical scenes carrying symbolic meanings is the disappearance of the moon. The story, written in the tradition of the Hasidic thinker Rabbi Nahman of Bratslav (1772-1811), draws on the Yiddish folktale of two Hasidic Jews who find a boat that takes them to the moon. They discover silver there, and in their greed they load the boat with it. However, the heavy boat begins to fall, and pulls the moon down with it. In Skibell's novel, the absence of the moon symbolizes the hard times experienced by the Jews and their persecution by the Nazis. Its disappearance is analogous with the disappearance of almost six million Jews. It is no coincidence that in Skibell's novel the moon, buried in the Earth, is at the same time the burial place of the Jewish victims, alluding to their extermination. The vanishing moon also functions to illuminate anti-Semitism; this is palpable in the episode in which the Polish family (Chaim's neighbors) ascribes responsibility for the disappearance of the moon to Jews (echoing the head of the German perpetrator). When one of the cousins doubts their guilt, another family member counters: "The yids disappear and the moon disappears and you're telling me they didn't take it?" (27). And their conversation continues in severely anti-Jewish tone: "'But Andrzej, you think they'll stop with the moon?' cousin Zygmunt says. 'Soon they'll want the stars and then the entire planetary system!" (27). Their entire talk is a travesty of the conspiracy theory about the plot to install a global Jewish hegemony, as if taken from The Protocols of the Elders of Zion. Although Skibell does not highlight the question of theodicy, the central motif also represents the absence of God for Jews during the Holocaust and the dark times of the disrupted continuity of Jewish life in the aftermath. Since Jews without the moon are unable to count Shabbes, the novel's central symbol implies their uncertainty.

The polysemous nature of this encompassing symbol becomes evident especially in the poetic scene depicting the exhumation of the moon from the mass grave of the murdered Jews. The restoration of the moon to the sky revives the faith that was diminished by its loss, and at the same time it implies a restoration of justice. It is telling that after this rebirth, Chaim enters the long-coveted World to Come, which represents a deliverance for him. As Grimwood claims, "Chaim is finally released from his suffering" (2007: 84). The release of the moon and its flight to the sky also suggests the new hope for the Jewish people in spite of all the horrors that they experienced during the historical catastrophe. This hope is contained in the ritual of blessing of the moon, which "provides an opportunity for praying to God the Creator of the universe" (Berger 2010: 154). However, the moon is not the same as in pre-war times. It is stained with blood and scarred with bullet holes. This change indicates the irreversibility of the course of events and the impossibility of ever returning to the previous state of the Jewish nation before the genocide: 
Standing on the stepladders when we need them, we scrub and rub, and although the mottling lightens, the stain is too deep. Our burnishing cannot make it disappear. ...we rub the moon down, drying it with towels until it gleams even more brightly than before, despite the mottling. Forever now, the moon will appear this way, no longer the smooth and gleaming pearl I remember from my youth. (244)

The stain here clearly signifies memory, a reminder of the dark past but also the loss of innocence. Irreversibility is reinforced by the symbol of the German soldier's broken glasses and the crack on Ola's toy telescope, conveying a world divided between the forces of good and evil. Marita Grimwood sees this as a disjuncture between "apparently irreconcilable worlds" (2007: 96). Any attempt to recover a prewar Jewish identity is doomed, as the losses are enormous and the scars too deep. Yet a toy compass, which Chaim received as a gift from Ola, evokes new hope and a promise of regained certainty.

Skibell's novel also contains other motifs that contribute to the reading of A Blessing on the Moon as an allegory; the most striking of these are the passages describing Jewish pilgrims' stay in the luxurious Amfortas hotel to which they are lured by the Germans, represented especially by the character of Herr Director. Though their experience with the German perpetrators urges them to be cautious and circumspect, the promise of comfortable accommodation with top-class services and excellent food causes the tired uprooted nomads to cast aside their initial distrust, so eventually they give in to temptation. The name of the hotel itself is symbolic: Amfortas was the King of the Grail Knights who succumbed to the magician Klingsor's intrigues and suffered a wound that could not be healed. In Skibell's novel, the hotel, surrounded by a magical river, is presented as a place where all the victims' traumas are to be healed. And indeed, at first the hotel seems to be a paradise, a sumptuous haven for the homeless Jewish wanderers. From the moment they enter Amfortas, the novel acquires absurd or grotesque features as the roles of perpetrators and victims are reversed. Jewish clients are served by German personnel with the utmost care and attention. Chaim, accommodated in a spacious apartment and provided with a new suit and a cigar, is absolutely puzzled by this new situation. As he confesses, "I am quite unprepared to see that not only does the coat seem the perfect size, but it looks exquisitely tailored. Indeed, I peel back the front lapel and read: Custom tailored for Chaim Skibelski by Schwartz \& Schneider, Fine Tailors of Germany" (135). After a long period of suffering, the Jewish "guests" feel human at last. Having been systematically degraded, they have already forgotten their humanness. This explains why in one scene all of them claim that the soup served to them tastes the same as their own mother's. They have even succumbed to the false illusion that they have already reached the desired World to Come. Furthermore, the hotel becomes the site of Chaim's reunion with his family. Seated at the table with his children and sons-in-law (whom he fails to recognize), he painfully realizes that no members of his family have survived; all of them have perished or disap- 
peared, including his grandchildren, who were seated at nearby tables, and his second wife Ester.

Yet Chaim remains alert, plagued by doubts about what is reality and what is chimera. His wariness is justified because he is aware of the delusiveness of the place. This delusiveness is intensified by the mirrors in the banquet hall, which create an impression of endless space, stretching the room to infinity. This can be interpreted as a deceptive illusion of the multiplied size of the Jewish community and falseness of the entire setting. Moreover, the distorted reality is underscored by the image of the convex faces, reflected in a monocle, which conveys the unreality of the location. Since Chaim Skibelski sees only those Jews who were massacred by the Nazi squad in his village, he rejects the illusion of being in the World to Come:

Of course, if this were the World to Come, wouldn't all the dead be here and not just the recently murdered? As I say, I had hoped to see my mother. And I had heard, for instance, that one encounters Adam and Abraham and, very usually, the prophet Elijah, none of whom are here. Otherwise, surely, they would have been called upon for speeches. (159)

Eventually, the Amfortas hotel turns out to be a trap. It emerges that the Jews, like King Amfortas, have become the victims of Germans' intrigues and perfidy, being entrapped in another site of genocide. Skibell uses the image of the hotel as an allegory of the death camps and their gas chambers. In fact the hotel is a replica of Auschwitz or any other site of the Holocaust's death machinery. Already the custom-tailored suit that is allotted to Chaim has an allegorical meaning, and can be interpreted as an ironic allusion to the prisoners' uniforms that concentration camp inmates had to wear. The reader discovers that all the Jewish guests who had appointments for the steam bath in the hotel laundry room have disappeared, having been gassed and baked in the ovens. It is their second death, now the ultimate one. The only "survivor" is the dead Chaim, purely because he overslept and missed the appointment in the bath. The steam bath in the hotel laundry room corresponds to the gas chambers, and the kitchen with its ovens represents a parallel to the crematoria. Considering the motif of ovens, it is instructive to note Skibell's allusion to the Grimm Brothers's fairy tale "Hansel and Gretel." The head baker apparently revels in baking Jews in ovens, and his exclamation "[t]here will be again sweetness in the world" (181) indirectly refers to the sweet smell of smoke over the crematorium chimneys in the death camps, which only reinforces the allegorical character of the depiction of the hotel. Intertextuality, in accordance with postmodern literature, has a firm place in A Blessing on the Moon-besides the fairytale elements (which can be also found in Chaim's encounter with the wolves and in the character of the Director, like a Pied Piper beckoning Jewish pilgrims to his hotel), the author was also inspired, as has been mentioned above, by Jewish folklore. This can be understood as a manifestation of "attempts to narrate Holocaust experience within the framework of traditional narrative forms" 
(Adams, 2011: 17). Since authors writing about the Holocaust face the question of the (in)ability of language to represent the horrors of the Nazi genocide, to speak the unspeakable, to find an adequate expression for all the extremities of the systematic extermination of the Jews and the other "unwanted" population groups, they return to the texts of their precursors. The transposition of these texts into Holocaust experience, be it fairy-tales or Hasidic tales, helps to familiarize the inexplicable terrifying events through stories and language that are familiar to readers; these texts bring about a process of familiarization in an otherwise defamiliarized magical realist text. Furthermore, they demonstrate the continuation of a Jewish cultural tradition that was violently interrupted by the Holocaust.

The closing section of Skibell's novel is written in mournful tone, caused by the narrator's grief over the irreplaceable losses and heightened by his awareness of the "second" loss of his family:

I close my eyes and see only the ovens and their flames, their blue tongues licking across the bodies of my Ester, my Sarah, my Edzia, my Miriam, my Hadassah, my Laibl; consuming my sons-in-law and their children, Markus, Solek, Israel, Pavel, Pola, Jakob, Sabina, Marek and his daughters; devouring my town as well. Everyone I know, everyone I have ever known, has disappeared into the ash. I have torn my clothes and fallen to my knees, but my grief is insufficient. Were the oceans made of tears and the winds of sighing, still there would not be tears enough nor sighs to assuage my crumpled heart. (191-192)

This sense of sorrow is emphasized by the protagonist's reciting the prayer Kaddish for his own death since he has no children to pray for him.

In conclusion, having very limited knowledge of his great-grandfather's fate in World War II due to the silence about the Holocaust in his family, Skibell by no means attempts to give a realistic or objective portrayal of Chaim Skibelski or a literal account of the events of the Holocaust. Instead, his project involves the use of a rich imagination, incorporating elements of magical realism, fantasy novels, allegory, Jewish folk tales and fairy tales. The fusion of realistic and fantastic elements in the fashion of magical realism is a dominant feature of his prose - as if he were aware that magical realism is a mode that offers a plurality of interpretation of such traumatic events, of the "history that is hard to comprehend" (Grimwood 2007: 107). There is one important argument against his critics who have accused him of the aesthetic appropriation of the Holocaust (for example the already mentioned Alvin Rosenfeld). The main subject of Holocaust literature is the depiction of the harrowing trauma of the genocide during World War II. However, as we know from trauma theory, objective knowledge of traumatic events is in fact impossible. As Cathy Caruth, one of the leading experts in the field of trauma theory, says, "[a traumatic event] is not fully perceived as it occurs; or put it somewhat differently, ... a history can be grasped only in the very inaccessibility of its occurrence" (1996: 18). Therefore magical realism, the 
fantastic, allegory and the other expressions of imagination should be regarded as entirely legitimate narrative strategies in Holocaust fiction. They enabled Skibell, through this ghost story about Jewish characters, to convey the prolongation of their suffering and thus their immeasurable ordeal during and after the Holocaust. In Jenni Adams' view, "[m]agic realist elements thus form an integral part of the text's pursuit of a viable means of approaching the Holocaust as an object of knowledge and representation" (2011: 49). Paradoxically, through traumatic imagination, they make events which resist their representation, and which are considered unspeakable, more accessible. Allegory enabled Skibell to evoke the historical reality of the Holocaust and to strengthen the realistic background of his otherwise imaginative story. Skibell's novel is not only about immense losses, but also about the continuity of Jewish life in spite of its rupture. As has already been suggested, the sense of this continuity, and the viability of Jewishness and Judaism, are underscored by the author's incorporation of motifs from Jewish (Hasidic) folk tales, representing tradition.

There can be no doubt that Skibell's novel enriches the existing canon of Holocaust literature by the use of innovative narrative strategies. It confirms Stephen's Gunther's assertion that "[n]ovels like A Blessing on the Moon demonstrate that there exists a growing willingness among contemporary writers to depart from the tradition of documentary realism that has so long dominated the majority of artistic responses to the Holocaust" (2000: 201). Skibell's novel represents a postmodern approach to the historical trauma of World War II by the new postHolocaust generation - an approach which necessarily differs from the first generation of authors-survivors, departing from a rigid claim of historical authenticity, due to the new generation's different life experience, spared from the worst evils that their less fortunate predecessors were forced to endure.

\section{Acknowledgements}

This article is part of the research project SGS11/FF/2015, University of Ostrava, "America as the Promised Land? Representation of Immigration in Selected Works of American Literature." It is also the result of my co-operation with the Hadassah-Brandeis Institute.

\section{References}

Aarons, Victoria (2012) 'The Certainties of History and the Uncertainties of Representation in PostHolocaust Writing.' Studies in American Jewish Literature 31 (2): 134-148.

Adams, Jenni (2011) Magic Realism in Holocaust Literature: Troping the Traumatic Real. Basingstoke: Palgrave Macmillan, 2011.

Arva, Eugene L. (2008) 'Writing the Vanishing Real: Hyperreality and Magical Realism.' Journal of Narrative Theory 38 (1): 60-85.

Bellow, Saul (1973) Mr. Sammler's Planet (1970). London: Penguin Books. 
Berger, Alan L. (2010) 'Unclaimed Experience: Trauma and Identity in Third Generation Writing about the Holocaust.' Shofar: An Interdisciplinary Journal of Jewish Studies 28 (3): 149-158.

Bukiet, Jules Melvin, ed. (2002) Nothing Makes You Free. Writings by Descendants of Jewish Holocaust Survivors. New York and London: W. W. Norton.

Caruth, Cathy (1996) Unclaimed Experience: Trauma, Narrative, and History. Baltimore and London: The Johns Hopkins University Press.

Danow, K. David (1995) The Spirit of Carnival: Magical Realism and the Grotesque. Lexington: University Press of Kentucky.

Faris, Wendy B. (2005) 'Scheherezade's Children: Magical Realism and Postmodern Fiction.' In: Lois Parkinson Zamora and Wendy B. Faris (eds.) Magical Realism: Theory, History, Community. Durham and London: Duke University Press, 163-190.

Felman, Shoshana (1995) 'Education and Crisis.' Trauma: Explorations in Memory. Ed. Cathy Caruth. Baltimore and London: The Johns Hopkins University Press, 13-60.

Franklin, Ruth. (2011) A Thousand Darknesses: Lies and Truth in Holocaust Fiction. Oxford and New York: Oxford University Press.

Giles, Patrick (1997) 'Review of A Blessing on the Moon.' New York Times Book Review 28 December: 12 .

Grimwood, Marita (2007) Holocaust Literature of the Second Generation. New York: Palgrave Macmillan.

Gunther, Stephen (2000) From Remembering Accurately towards a Hermeneutics of Memory: Representation of the Holocaust in Contemporary Fiction. Dissertation. Waltham: Brandeis University.

Hirsch Marianne (2008) 'The Generation of Postmemory.' Poetics Today 29 (1): 103-128.

Rosenfeld, Alvin (1997) 'Two Mystical First Novels Haunted by Visions of Evil.' Forward 31 October: $15-16$.

Sicher, Efraim (2005) The Holocaust Novel. New York: Routledge.

Skibell, Joseph (1998) A Blessing on the Moon (1997). London: Little, Brown and Company.

Sokoloff, Naomi B. (1992) Imagining the Child in Modern Jewish Fiction. Baltimore: Johns Hopkins University Press.

Spindler, William (1993) 'Magic Realism: Typology.' Forum for Modern Language Studies 29: $75-85$.

Stadden, Pamela (2005) 'Narrative Techniques and Holocaust Literature: Joseph Skibell's A Blessing on the Moon.' Studies in American Jewish Literature 24: 153-157.

Todorov, Tzvetan (1975) The Fantastic: A Structural Approach to a Literary Genre, trans. by Richard Howard. Ithaca, NY: Cornell University Press.

Volpi, Jorge (2014) 'Děti bez prasečích ocásků.' A 2 (25): 18-19.

Stanislav Kolář is a member of the Department of English and American Studies, Faculty of Arts, University of Ostrava, Czech Republic, where he teaches courses on American Literature and American Studies. He is the author of monographs Evropské kořeny americké židovské literatury (1998, The European Roots of Jewish American Literature) and Seven Responses to the Holocaust in American Fiction (2004). With the co-authors Zuzana Buráková and Katarína Šandorová he has published a monograph entitled Reflections of Trauma in Selected Works of Postwar American and British Literature (2010).

Address: Stanislav Koláŕ, Department of English and American Studies, Faculty of Arts, University of Ostrava, Reální 5, 70103 Ostrava, Czech Republic. [email: stanislav.kolar@osu.cz] 